\title{
POEM BY A. A. AKHMATOVA \\ "I SEE A BRILLIANT FLAG OVER CUSTOMS ..." (RESULTS OF EXPERIMENTS OF REAL AND POETOLOGICAL COMMENTARY)
}

Kazarin V. P.

\section{INTRODUCTION}

In the autumn of 1912, A. A. Akhmatova wrote the poem "I See a Faded Flag Above Customs...". We allow to remind the reader this text:

Вижу выцветший флаг над таможней

И над городом жёлтую муть.

Вот уж сердце мое осторожней

Замирает, и больно вздохнуть.

Стать бы снова приморской девчонкой,

Туфли на босу ногу надеть,

И закладывать косу коронкой,

И взволнованным голосом петь.

Всё глядеть бы на смуглые главы

Херсонесского храма с крыльца

И не знать, что от счастья и славы

Безнадёжно дряхлеют сердца ${ }^{1}$.

The poem was published in the February issue of Hyperborea magazine in 1913. So, it was written no later than 1912: manuscripts were submitted to the magazines two months before publication. The author's dating "Autumn 1913" in Akhmatova's book "Running of Time" ${ }^{2}$ correctly indicates the season when the poem was created, but not a year. In January 1913 it was already in the printing house. In addition, to the end of 1912 (judging by the manuscripts and copyright certificates) the most of the other poems of Akhmatova's collection (five in total, our poem in the middle - the third) were published in the same journal ${ }^{3}$. And the very atmosphere of the poem, filled with the

${ }^{1}$ Ахматова А. А. Собрание сочинений. В 6 т. - Москва: Эллис Лак, 1998-2002; Т. 7 (дополнительный). - 2004. - С. 117.

2 Ахматова А. А. Стихотворения и поэмы / Составление, подготовка текста и примечания В. М. Жирмунского. - Издание 2-е. - Ленинград: Советский писатель, 1977. (Библиотека поэта. Большая серия). - С. 71, 758.

${ }^{3}$ Ibid. C. 456. 
departing summer heat, also compels its plan with the autumn of 1912, and not with the winter of 1913.

In the final version, the poem has no name. But it was originally published under the title Return, and it is not by accident. Compositionally, the whole poem is built on a mental "return" from the present to the past. Only having in mind this parallel contrast, you can penetrate into its plan from Akhmatova's realities.

\section{1. Вижу выцветший флаг над таможней <...>}

What kind of customs does the poet write about? Where could one see her flag?

The main maritime customs of St. Petersburg was at the beginning of the twentieth century on the spit of Vasilyevsky Island in the building in which the Institute of Russian Literature (Pushkin House) of the Russian Academy of Sciences has been located until 1927. The verb in the first line of the poem implies the duration of the action: did not "see" or "notice" the customs flag, did not "look" or "glance" at it, but "see". Not simultaneously, but continuously, not once, but repeatedly, again and again. Why, then, did Akhmatova see customs again and again for some time?

In the capital at that time, our poet for more or less long without a change of place remained in only one institution - in the so-called clinic of Professor D. O. Ott. The clinic was founded by Empress Maria Fedorovna in 1797. Today it is the D.O. Ott Institute of Obstetrics and Gynecology. In this very "imperial maternity hospital", as St. Petersburgers called it, on September 18 of 1912, Akhmatova gave birth to a son - Leo.

The clinic of Professor D. O. Ott, "very expensive and very well furnished" ${ }^{4}$, where N. S. Gumilyov brought his wife to give birth, has been located on the spit of Vasilyevsky Island, just south of the customs building now Pushkin House (see Fig. 1).

The three-story building of the Maritime Customs is crowned with a round tower, which is quite a bit inferior in height to its architectural basis and lonely rises above the entire district. A spire is installed on the dome of the tower, the length of which is equal to the floor of the main building (see Fig. 2)

It was the spire on the round tower of the building that carried the flag of the Russian Maritime Customs Office, which was approved on March 1, 1871, the blue flag with the national tricolor in the canton and crossed caduceus (wands of Mercury) entwined with snakes (see Fig. 3).

4 Черных В. А. Летопись жизни и творчества Анны Ахматовой: 1889-1966. Издание 3-е, исправленное и дополненное. - Москва: Издательский центр «Азбуковник», 2016. - C. 89. 


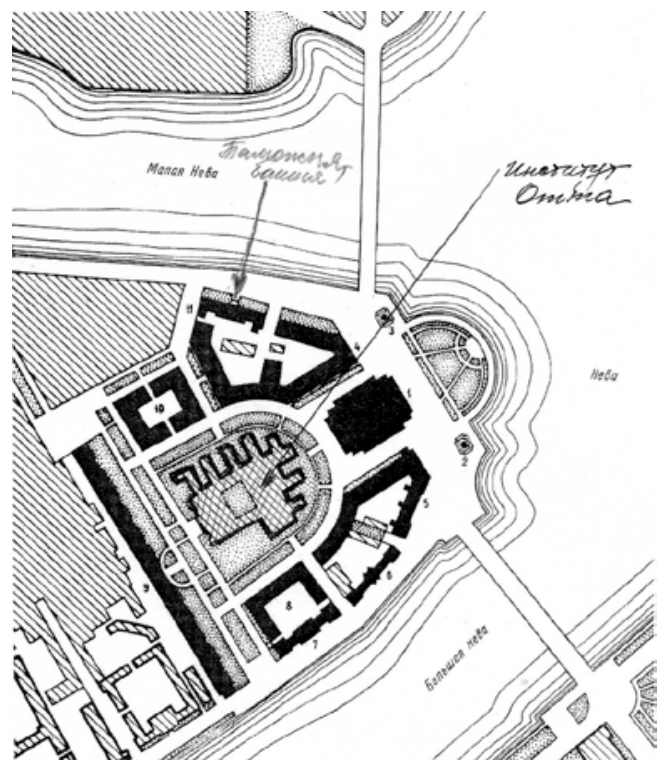

Fig. 1. Spit of Vasilyevsky Island

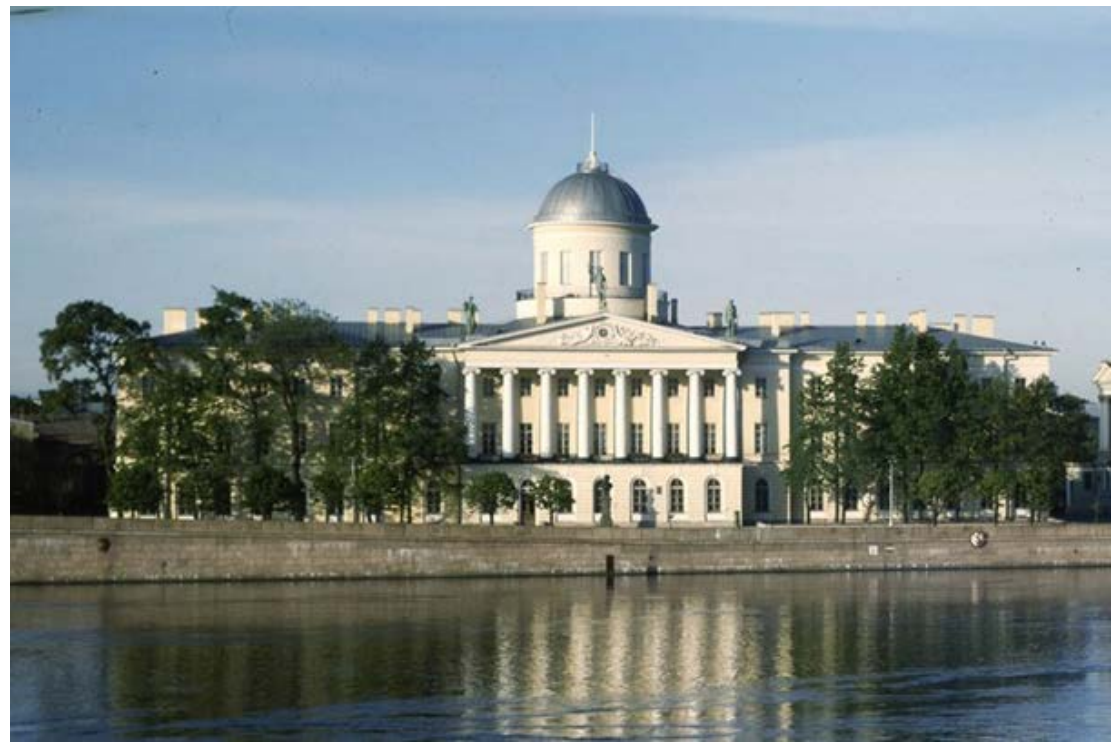

Fig. 2. The building of the main Maritime Customs in St. Petersburg 


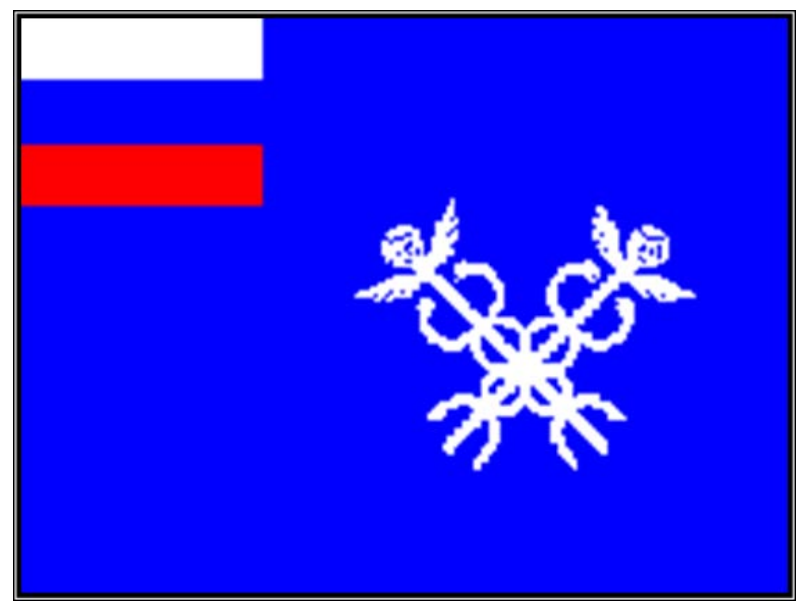

Fig. 3. Russian Maritime Customs Flag

The customs flag was visible far in the county. A. A. AkhmatovaGumilyova, obviously, was in the ward on the north side of the clinic. It was from there she could see through the window not only the "yellow haze" of the autumn sky, but also the "customs flag".

All of the above suggests that the poem we are analyzing was written no earlier than the last days of September, when the poet goes to the clinic of Professor D. O. Ott. Not earlier, but it may be written two or three weeks later. On October 22, 1912, Akhmatova wrote a letter to V. Ya. Bryusov, in which she sent him "several poems written the other day," and left an important confession: "I could not do this before, because I had a baby and I haven't written anything at all” .

\section{2. <...> И над городом жёлтую муть}

Actually, Akhmatova writes that she sees «жёлтую муть» - «над городом». Indeed, it is not the city itself that opens to the bed patient, but the space above it - with a faded flag and yellow-hazy skies. Moreover, it can reasonably be assumed that our woman in childbirth was not on the first, or even hardly on the second floor of the clinic. Otherwise, neighboring buildings and trees (and the spit is built up very densely) would obscure any view from the window, including the sky.

5 Черных В. А. Летопись жизни и творчества Анны Ахматовой: 1889-1966. Издание 3-е, исправленное и дополненное. - Москва: Издательский центр «Азбуковник», 2016. - C. 90 . 
But why is her sky «мутное»? And why - «жёлтое»?

With «мутью» the situation is more or less simple. In September 1914, when St. Petersburg was already renamed Petrograd, A.A. Blok would write one of his most famous poems - about the military echelon of the First World War, departing from the capital for «кровавые поля»Galicia. The first line of the poem, which gave it a name, sounds like this:

Петроградское небо мутилось дождём $<\ldots>^{6}$.

So, the first version is rain. The second version is fog. The end of September for the north is already autumn. It would be possible to check both versions from the metropolitan newspapers of September 1912. Weather forecasts were already published regularly, as they are now. But there is also the internal optics of the Akhmatova's poem itself. She dismisses both of these versions. It is still possible to see the flag above the customs through rain or fog. To see that wet flag «выцветший», - it is impossible.

The third version, mentioned above, remains. Not the air of St. Petersburg is muddy and yellow, but the sky, through which the Baltic is already catching low swirling clouds. But where did this yellow color come from?

From electric lights. For the beginning of the twentieth century, bright electric street lighting is still a curiosity and a prerogative of capitals. We will find many poems about this in A. A. Blok, in the early V. V. Mayakovsky, and in other St. Petersburg poets. In the artificial yellowness of night megacities, sometimes they saw something devilish: everything replacing, depreciating, distorting. But our poet also has a quite positive perception of new-fangled lamps: «Чернеет дорога приморского сада, / Желты и свежи фонари» ${ }^{7}$.

If we accept our explanation of the appearance in the poem «жёлтой мути», it turns out that Akhmatova fixes her round-the-clock stay in the clinic. During the day, she sees a customs flag, at night - the low sky, dull and yellow from electric lamps. This indicates some kind of anxiety experienced by her. Anxiety turns into insomnia.

\section{3. Вот уж сердце мое осторожней замирает, и больно вздохнуть}

From a medical point of view, the situation is clear. The heroine of the poem has all the symptoms of heart failure. She has the suddenness of the attack ("that's it..."), interruptions in the heart rate, and acute pain in the sternum when inhaling. In her letter to S. V. von Stein (1907), she mentions another symptom

${ }^{6}$ Блок А. А. Собрание сочинений. В 8 т. - Москва-Ленинград: ГИХЛ, 1960-1963. T. 3. - C. 273.

T. 1. - C. 175 .

7 Ахматова А. А. Собрание сочинений. В 6 т. - Москва: Эллис Лак, 1998-2002; 
of the disease: "My heart is very bad and it only gets sick, my left hand is

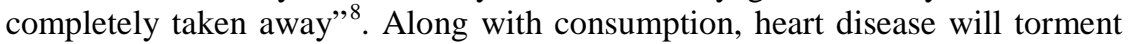
Akhmatova all her life - she will eventually die from it. Poems of our poet (as always, documented for sure!) record the development of this ailment.

But what could provoke it then - in September 1912?

Of course, childbirth is not an easy test for any woman, and even more so for a patient with tuberculosis. Yes, St. Petersburg weather («жёлтая муть») is not good for her heart. And yet ... One gets the impression that something happened in Akhmatova's inner life just before or right after the birth that hit her heart.

What torments our woman in childbirth in the clinic? What does she hide so carefully? Why does the poet not say a single word that he became a mother in a poem? Why does the poem stubbornly date in the autumn of 1913 in subsequent editions, actually disorienting the reader? What should the reader not know about her period in 1912?

We will call this the "little secret" of the poem. We will have to return to it a bit later. In the meantime, poetry makes an unexpected leap in time and space.

\section{4. Стать бы снова приморской девчонкой, Туфли на босу ногу надеть, И закладывать косу коронкой, И взволнованным голосом петь}

In dreams, the heroine in the second stanza is instantly come back: to the happy teenage childhood that passed there - by the sea, in Sevastopol. This is understandable to the reader without any comments. Does he understand otherwise?

Swift, easy rhythm. Not a single anjambament, unlike the previous lines, with their physically lack of breath (heart «осторожней / замирает...»). Sound vocalism. Simple, colloquial vocabulary. The poet really "returned", she is at home - both mentally and physiologically. Finally, she is well.

At what price?

And the very one that, having returned (let, we repeat, in dreams), the heroine seemed to annul everything that happened to her in the interval between «приморской девчонкой» 1896-1903, а poet and a woman of the year 1912. Renunciation is recorded element by element. «Косы коронкой» орроse the famous, emblematic straight fringe and hair, casually pinned with long stilettos

8 Черных В. А. Летопись жизни и творчества Анны Ахматовой: 1889-1966. Издание 3-е, исправленное и дополненное. - Москва: Издательский центр «Азбуковник», 2016. - C. 51. 
in a fashionable Japanese way. But this hairstyle was and will be captured on the canvases of famous artists.

The same can be said about the suit. A yellow shawl, which, according to one version, will be brought by Akhmatova's husband from a trip to the East, and other "false-classical shawls" written by O.E. Mandelstam; agate and amber rosary on the neck; defiant lines that shocked the audience of the Silver Age: «... Я надела узкую юбку, / Чтоб казаться еще стройней» ${ }^{9}$, everything is discarded. Happiness, it turns out, is hiding in a simple one "wear shoes on your bare feet".

Akhmatova, unusually flexible by nature, fascinated the guests in her and N. S. Gumilyov Tsarskoye Selo home with "serpentine" acrobatic pirouettes: she "easily laid her foot behind her neck, touched the back of her heels" 10 . With all the abundance of "orgies" and "Athenian nights" in the stylized everyday life of the Silver Age, nobody seems to have allowed such virtuoso extravagancies. But the "witch-wife" was dreamed of, as it turns out, about something completely different - she wants only to "sing with an excited voice".

All the roles - worked out over the years by N. S. Gumilyov imperiously and meticulously honed - turned out to be painful and unnecessary.

What about a newborn son? And husband? But creativity and glory?

Volumes of scientific works have been written about the dialogism (or polylogism) of Akhmatova's lyrics, about its special plot. However, none of the scholars seem to have focused on the fact that dialogue is a conversation between two parties (and not a monologue in the presence of the other). And the plot is events that are differently significant for different heroes (and not just for the subject of the action, for whom all the others are only objects).

The "small" mystery of the poem, analyzed by us, is a dialogue in encrypted form, and it is addressed to N. S. Gumilyov. Their marriage, which had already lasted two and a half years, did not make the two poets dearer and closer. On the contrary, alienation, opposition in everything (even in verses) only grew. Akhmatova sincerely rejoiced in the book of N. S. Gumilyov (1910), "Pearls" ("3/4 of the lyrics <...> refers to me").She perceived his book "Alien Sky" (1912) as a "fight” with her «не на живот, а на смерть!» ${ }^{11}$. Having returned in the spring of 1912 from a joint trip with her husband to Italy and was surprised to find that she cannot tell her loved one about this journey, so important for her internal development, "easily and smoothly," Akhmatova will

${ }^{9}$ Ахматова А. А. Собрание сочинений. В 6 т. - Москва: Эллис Лак, 1998-2002; T. 1. - C. 113.

${ }^{10}$ Черных В. А. Летопись жизни и творчества Анны Ахматовой: 1889-1966. Издание 3-е, исправленное и дополненное. - Москва: Издательский центр «Азбуковник», 2016. - C. 76.

${ }^{11}$ Ibid. C. 86. 
explain the difficulty quite naturally: "It must be "we (with N. S. Gumilyov Auth.) were not so close to each other anymore..." 12 .

The birth of a son will only confirm the apprehension expressed by Akhmatova in the poem "He loved..." (1910) - six months after the wedding. She first lists the "three things" that her husband loved. Then she calls three things that he does not like. The first among them is "when the children cry"13. It was this "thing" that happened - she gave birth. We will not touch the behavior of N. S. Gumilyov during his wife`s pregnancy and the birth of their child, though it caused her unhealed wounds. The marriage, legally decaying in 1918, actually died in the autumn of 1912. This is what Akhmatova herself will say: "Soon after the birth of Leva, we silently gave each other complete freedom and ceased to be interested in the intimate side of each other's life" ${ }^{14}$.

But the wound remained, and the heart hurt. That is why Akhmatova's poem is really addressed to him - N. S. Gumilyov. He alone knows where she could see "выцветший флаг над таможней" again and again. Defending her drama from strangers, Akhmatova does not mention the clinic, she does not utter a word about childbirth, about her son. She only allows herself, revealing the accumulated anxiety and longing, to describe the sky over Petersburg as “жёлтую муть", and call the flag above the customs "выцветшим". She did not say and will never say so about the sky over Chersonesos, about the flag over the Sevastopol customs.

N. S. Gumilyov understood the intention of his wife and reacted to the message addressed to him. April 9, a month and a half after the publication of the poem, he from Odessa, before his next departure to Africa, openly answered. It will start from afar - with the general characteristics of the poem and determining the place of its author in poetry: "I remember your lines all day about the "seaside girl", not only do I like them, they get me drunk. "So much has been said so simply, and I am absolutely convinced that out of all the post-symbolic poetry, yes, perhaps (in your own way), Narbut will turn out to be the most significant" 15 .

The answer is unexpected, and in some places doubtful. Firstly, it turns out that not only Akhmatova is dreaming of a happy "seaside girl", N. S. Gumilyova also does not just "like" her, she makes him "drunk". He chooses not the Kiev "sorceress", not the Tsarskoye Selo "nymph", not the

${ }^{12}$ Ахматова А. А. Собрание сочинений. В 6 т. - Москва: Эллис Лак, 1998-2002; T. 1. - C. 553.

${ }^{13}$ Ibid. C. 36.

${ }^{14}$ Черных В. А. Летопись жизни и творчества Анны Ахматовой: 1889-1966. Издание 3-е, исправленное и дополненное. - Москва: Издательский центр «Азбуковник», 2016. - C. 89.

${ }^{15}$ Гумилёв Н. С. Сочинения. В 3 т. - Москва: Художественная литература, 1991. T. 3. - C. 236. 
acmeistic queen, but that simple-minded, naive, joyful "wild girl”. But after all, N. S. Gumilev himself sculpted the nymph and queen from Akhmatova for years? Yes. But Pygmalion, apparently, could not stand the fact that Galatea outgrew him.

Secondly, N.S. Gumilyov's reasoning about Akhmatova paired with V. I. Narbut is not really believed in sincerity. Actually, N. Gumilyov's artistic flair was sharp and precise. He could not help but feel that V. I. Narbut was not comparable in talent with Akhmatova. Therefore, this comparison does not magnify, but reduces the scale of her personality.

But what about family matters?

From the same Gumilev's letter: “Dear Anya, I know that you don't like and don't want to understand this, but I'm not only joyful, but also directly necessary as you deepen for me as a woman, to strengthen the man in myself"; "I could never have guessed that hearts and happiness would hopelessly decay because of happiness and glory, but you would never have been able to explore the land of Gallus and understand when you see the moon that it is the diamond shield of the goddess of Pallas warriors” ${ }^{16}$.

It would seem, why here, in a letter to a yearning and more recently close woman, all these studies of the "country of Gallus" and "diamond shields" of the goddess Pallas? But this is creative jealousy. Akhmatova's destiny is to say "so simple - so much". His destiny was to go to distant Africa, explore the people of the Galla giants (the highlands of West Africa in the upper reaches of the Blue Nile, north of Somalia), and study Hellenic mythoculture. (By the way, here N. S. Gumilyov made several inaccuracies: the Moon was never Athena's shield, especially diamond, as Athena herself was not the goddess of warriors.)

All this is already a clear concern for the "descendants", which, according to the "sweetheart" wife, should "judge" them with N. S. Gumilyov:

$<\ldots>$ Чтоб отчётливей и ясней

Ты был виден им, мудрый и смелый,

В биографии славной твоей

Разве можно оставить пробелы? ${ }^{17}$

And the fact that these words were spoken in the last - fifth! - a poem from the Akhmatova's compilation of the February issue of Hyperborea, allows us to conclude that not one, not two, but all of them are testimony and the visible result of the painful separation from the "not beloved" wife with the "not beloved" husband in late 1912. Moreover, not only the composition of the poetic selection is important («Смятение», «Умирая, томлюсь о

${ }^{16}$ Гумилёв Н. С. Сочинения. В 3 т. - Москва: Художественная литература, 1991. T. 3. - C. 236.

${ }_{17}$ Ахматова А. А. Собрание сочинений. В 6 т. - Москва: Эллис Лак, 1998-2002; T. 1. - C. 114. 
бессмертьи...», «Вижу выцветший флаг над таможней...», «И на ступеньки встретить...», «Столько просьб у любимой всегда...»), but also the order in which these five poems were printed.

Referring to his verses "Galla" (so far in the plan) and "Odyssey at Laertes”, N. S. Gumilev actually acknowledges the correctness of Akhmatova's reproaches, speaks of the impossibility of changing anything on his part and offers her that very agreement on complete mutual freedom , about the "silent" conclusion she wrote. The search for "happiness" and "glory" brought him fame, but deprived the hero's heart of the ability to love, "hopelessly" him “одряхлив".

N. S. Gumilyov only confirms this in his letter. He believes that on the basis of the "silent" agreement that they must conclude, friendly creative relationships can be restored. Yes, both of them are no longer connected by love, but the status of leaders of modern culture, as well as the family, continues to bind: "It is curious that now I am again the same as when the Pearls were written, and they are closer to me from the Alien Sky. <...> Kiss the Lioness from me (funny, I'm writing his name for the first time) and teach him to speak dad"18.

And this part of the Gumilev's letter, too, from a third perspective, is not perfect. The young father leaves his six-month-old son and his nursing mother for the sake of a "creative" trip to distant lands. In what expressions does he convey his feelings? "Curious...". "Funny...”. It is as if he is not detaching himself from the family for a long time, but is carefully observing himself.

Another eloquent detail. Poets do not give random names - neither to their characters, nor to their loved ones. Marina Tsvetaeva called her son the victorious name George. Anna Akhmatova named the child the royal name of Leo. From "Leo" the husband (also a poet!) Makes a ridiculous nickname "Lioness", as if referring to a home toy.

This letter is unlikely to testify the "happiness" of the GumilyovAkhmatova family. Now, having restored the Petersburg context of the poem, we can return to its Crimean context.

\section{5. Всё глядеть бы на смуглые главы \\ Херсонесского храма с крыльца <...>}

Chersonesos Church is the St. Vladimir Cathedral in Chersonesos. However, most of the comments in the collected works of Akhmatova to the poem “Вижу выцветший флаг над таможней...” avoid answer the questions:

${ }^{18}$ Гумилёв Н. С. Сочинения. В 3 т. - Москва: Художественная литература, 1991. T. 3. - C. 236. 
why is the poet's dome of the cathedral called "dark" and why did he find the plural ("chapters") in her verses ${ }^{19}$ ?

Relying on the author's biographical notes, commentators actually look for an answer to only one question: where exactly in Sevastopol in her childhood the poet could "look" at the Chersonesos Cathedral "from the porch". For example: "We are talking about the cottage "Отрада" ("New Chersonesos") on the shore of Streletskaya Bay - "the cottage Tur", three miles from Sevastopol, where the Gorenko family spent every summer from 1896 to 1903”20. Or: "In the country house Tur («Отрада») near Sevastopol, Anya Gorenko lived with her parents every summer in 1896-1903”21.

The two-volume volume of 1990, along with other inaccuracies, mistakenly identifies the time of writing the poem with the time of the memoirs contained in it. So, we read: "It is written at the cottage «Отрада» ("New Chersonesos") three miles from Sevastopol on the banks of Streletskaya Bay, where Akhmatova spent every summer from 7 to 14 years" ${ }^{22}$. It turns out that the poem of 1912 was created in 1903, that is, a fourteen-year-old teenage girl. In fact, of course, the poet returns to her past in thoughts, and does not abide in it in reality. Recall: in the journal Hyperborea, the poem was published under the title "Возвращение", 23.

Once again, we are convinced: without a thorough study of the realities of time and place, even autobiographical notes of a writer cannot be read correctly. Verily, as she herself stated, "people see only what they want to see, and hear only what they want to hear" 24 .

Contrary to the opinion cited above, Akhmatova did not live in the cottage of N. I. Tur. She herself will clearly say about this in one of her notes of the late 1950s - early 1960s: "In the vicinity of this dacha («Отрада", Streletskaya Bay, Chersonesos) I received the nickname "wild girl" <..> (highlighted by us. - Auth.)" ${ }^{\text {. }}$. It will be right to say that Akhmatova lived with her parents in the dachas of Tur.

19 Ахматова А. А. Собрание сочинений. В 6 т. - Москва: Эллис Лак, 1998-2002; T. 1. - С. 744. Ахматова А. А. Сочинения. В 2 т. - Москва: Художественная литература, 1986. - T. 1. - C. 393-394.

${ }^{20}$ Ibid. - C. $744-745$.

${ }^{21}$ Ахматова А. А. Сочинения. В 2 т. - Москва: Художественная литература, 1986. T. 1. - C. 394; T. 2. - C. 429.

${ }_{22}^{22}$ Ахматова А. А. Сочинения. В 2 т. - Москва: Правда, 1990. - Т. 1. - С. 376.

T. $1 .-$ C. 744

${ }^{23}$ Ахматова А. А. Собрание сочинений. В 6 т. - Москва: Эллис Лак, 1998-2002; T. 2. - C. 243 .

${ }^{24}$ Ахматова А. А. Сочинения. В 2 т. - Москва: Художественная литература, 1986. T. 5. - C. 215.

${ }^{25}$ Ахматова А. А. Собрание сочинений. В 6 т. - Москва: Эллис Лак, 1998-2002; 
Well-known to the Sevastopol estate N. I. Tur until 1905 was called "Отрада" 26 . The owner of the estate was an entrepreneurial man. On part of his land, he built a dacha village for vacationers. By the name of the owner, the village received the name Turovskaya Sloboda, or Turovka. Today Turovka is no longer to be found on the official city map. In 1923, initially, and in 1935 finally, the settlement was renamed in honor of the sailor G. N. Vakulenchuk, the organizer of the uprising on the battleship "Potemkin" ${ }^{27}$. It is very significant that in the oral tradition Turovka continues to live in Sevastopol until now, and the settlement of Vakulenchuk in the mass consciousness has not been fixed.

It was on this very Turovka that the Gorenko family rented a house almost every summer for eight years. "On the modern map of Sevastopol, the current Gagarin Avenue”, writes V. Sevastopol local historian Gorelov, "roughly corresponds to Turovsky highway, the main street of this village. It is hardly possible now to establish the location of the house where Anya and Inna Erasmovna Gorenko stayed..."28. One thing is clear: the house was located on an elevated part of the Turovskaya Sloboda. It was from there that Chersonesos and Streletskaya Bay were clearly visible. This was reflected in the poem of Akhmatova and in her memoirs.

After 1905, the estate «Отрада» was rebuilt in the spirit of the times. The new design of a restaurant, public garden, summer-houses, benches, outdoor areas appeared there. Having changed its appearance, the estate changed its name: it was renamed the "New Chersonesos". In this part of the city, Akhmatova appeared again only in 1907. She settled in the neighbourhood, in a new summer cottage - in the mud bath of Yev. E. Schmidt, which is located on the shore of Sand Bay. Its owner was a doctor, court adviser Yevgeny Eduardovich Schmidt, who lived in his own house on the same Ekaterininskaya street, where Akhmatova's grandfather also lived ${ }^{29}$.

Akhmatova undoubtedly saw the places of her childhood, which changed both the appearance and the name. This is evidenced by her recollections: “There are no Tur dachas («Отрада» or “New Chersonesos”) - three versts

26 Севастополь: Энциклопедический справочник. Издание 2-е, дополненное и исправленное. - Севастополь: «Салта» ЛТД, 2008. - С. 905.

${ }^{27}$ Ibid.- C. 147, 905.

${ }^{28}$ Горелов В. Н. Херсонес Анны Ахматовой // Литературная газета + Курьер культуры: Крым-Севастополь: Региональное обозрение. - 2008. - 26 сентября-10 октября. № $18(23)$. - C. 2.

29 Черных В. А. Летопись жизни и творчества Анны Ахматовой: 1889-1966. Издание 3-е, исправленное и дополненное. - Москва: Издательский центр «Азбуковник», 2016. - С. 53. Горелов В. Н. Херсонес Анны Ахматовой // Литературная газета + Курьер культуры: Крым-Севастополь: Региональное обозрение. - 2008. - 26 сентября-10 октября. № $18(23)$. - C. $2,13$. 
from Sevastopol, where from seven to thirteen years (correctly - up to fourteen. - Auth.) I lived every summer and received a nickname "Wild girl" $<$... (emphasis added by us. - Auth.)" ${ }^{\text {30 }}$.

By the way, the age correction introduced by us is indicative. A number of errors among commentators was made in the poet's memoirs. For example, everyone in the notes writes that she spent "every summer" at the Tur dacha. It should be written differently - "almost every summer”, since neither in 1898, nor in 1900, the Gorenko family did not rest there in the summer ${ }^{31}$.

After these necessary explanations, let us return to the Chersonesos Church.

St. Vladimir's Cathedral in Chersonesos was built in 1861-1891. Only the 2005 two-volume book rightly indicates that the cathedral dome was "незолочёным" "2. Indeed, the gilt at the cathedral was originally only a cross. The dome was covered with gold already during the restoration work of 19982004. Otherwise, this comment, unfortunately, has inaccuracies. St. Vladimir Cathedral was not built in 1862-1892. The cathedral has one dome, not several. From the Streletskaya bay this dome is not visible. It is visible (as we have already noted) from the hills bordering the bay. It was just the cottage rented by the Gorenko family.

The question remains unresolved: so what was the dome of the Chersonesos church in the late 19th and early 20th centuries?

The St. Vladimir Cathedral was built for the 900th anniversary of the St. Equal-to-the-Apostles Grand Duke Vladimir christening in Chersonesos. That is why the author of the project, academician D. I. Grimm, proposed to erect a cross-dome temple in Byzantine style. Among other things, this implied (in accordance with the Greek Orthodox tradition) the rejection of the dome gilding. (Compare three Sacred Sofia - cathedrals in Constantinople, Kyiv and Velikiy Novgorod). But the dome of the cathedral and its two-tiered roofs were covered for some reason not with copper (that was already a tradition), but with zinc tiles ${ }^{33}$. Presumably, because of the cost criteria. Zinc is a metal that is light enough. That is why the initial coverage was disrupted by the hurricane in December 1879. After that, repairs were carried out, the result was the

${ }^{30}$ Ахматова А. А. Собрание сочинений. В 6 т. - Москва: Эллис Лак, 1998-2002; T. 5. - C. 693 .

${ }^{31}$ Черных В. А. Летопись жизни и творчества Анны Ахматовой: 1889-1966. Издание 3-е, исправленное и дополненное. - Москва: Издательский центр «Азбуковник», 2016. C. 36, 38.

${ }^{32}$ Ахматова А. А. Победа над судьбой. В 2 т. - Москва: Русский путь, 2005. T. 2. - C. 433 .

33 Севастополь: Энциклопедический справочник. Издание 2-е, дополненное и исправленное. - Севастополь: «Салта» ЛТД, 2008. - С. 165. 
replacement of a part of the zinc roof (namely, cornices) with lead ${ }^{34}$. On the one hand, that made the roof heavier, having stored it from strong winds, on the other, - preserved the colour of the main coating, because lead in an oxidized state visually almost does not differ from zinc. The colour scheme of zinc is bluish-gray, that eventually tends to darkening. As a result, the zinc-lead dome and the gable two-tiered roofs of the cathedral in pre-revolutionary photographs «имеют тяжёлый сумрачный цвет» ${ }^{35}$.

All that gave Akhmatova the basis to talk about the "creamy chapters" of the Chersonesos temple. But why does she write about the only dome of the cathedral in plural?

Firstly, the commented verse had an original version. V.M. Zhirmunsky, publishing Akhmatova in the "Library of the poet", cites that early edition of the line we are interested in: «Херсонесских церквей у крыльца» ${ }^{36}$. Undoubtedly, it was about the ruins of numerous Byzantine basilicas of the V-IX centuries on the territory of Chersonesos, as well as the Orthodox churches of modern times - St. Vladimir Cathedral, the temple of seven Chersonesos martyrs, the house church of the Abbot Corps.

From a young age Akhmatova treated Chersonesos in a special way. It was "the main place in the world" ${ }^{37}$ for her. The "strongest impression" of teenage years was "the ancient Chersonesos, near which we lived"38. "Directly from here", according to the poet's self-evaluation, "antiquity - Hellenism"39 came to her.

At the same time, for our poet the accuracy of details is characteristic, we have repeatedly been convinced in that. «Главы» of the Chersonesos churches are devoid of gilding and they are really «смуглые». But they were not located at all «y крыльца» of the Akhmatova's summer house, although they were clearly visible from there. The distance to them was about two kilometers.

34 Золотарёв М. И., Хапаев В. В. Херсонесские святыни. - Севастополь: ФуджиКрым, 2002. - С. 97-98.

35 Горелов В. Н. Херсонес Анны Ахматовой // Литературная газета + Курьер культуры: Крым-Севастополь: Региональное обозрение. - 2008. - 26 сентября-10 октября. № 18(23). - C. 2.

36 Ахматова А. А. Стихотворения и поэмы / Составление, подготовка текста и примечания В. М. Жирмунского. - Издание 2-е. - Ленинград: Советский писатель, 1977. (Библиотека поэта. Большая серия). - С. 387.

37 Черных В. А. Летопись жизни и творчества Анны Ахматовой: 1889-1966. Издание 3-е, исправленное и дополненное. - Москва: Издательский центр «Азбуковник», 2016. - C. 32 .

38 Ахматова А. А. Собрание сочинений. В 6 т. - Москва: Эллис Лак, 1998-2002; T. 5. - C. 236 .

${ }^{39}$ Ibid. C. 215. 
This, apparently, prompts Akhmatova to abandon the early revision of the line, replacing it with the current one: «Херсонесского храма с крыльца». However, in the previous line, she leaves «смуглые главы» in plural, while the Chersonesos temple has only one dome. Why?

Visually (secondly) the image of the poet is completely accurate. St. Vladimir's Cathedral was designed in such a way that from afar it looks like a multi-domed temple. Numerous parts of its covering (from dome to roof fragments), have different forms (round, corner, square), but one colour at that period, and indeed look like separate "domes". Growing in the width, they drop three tiers - from the top to the base (see figure 4).

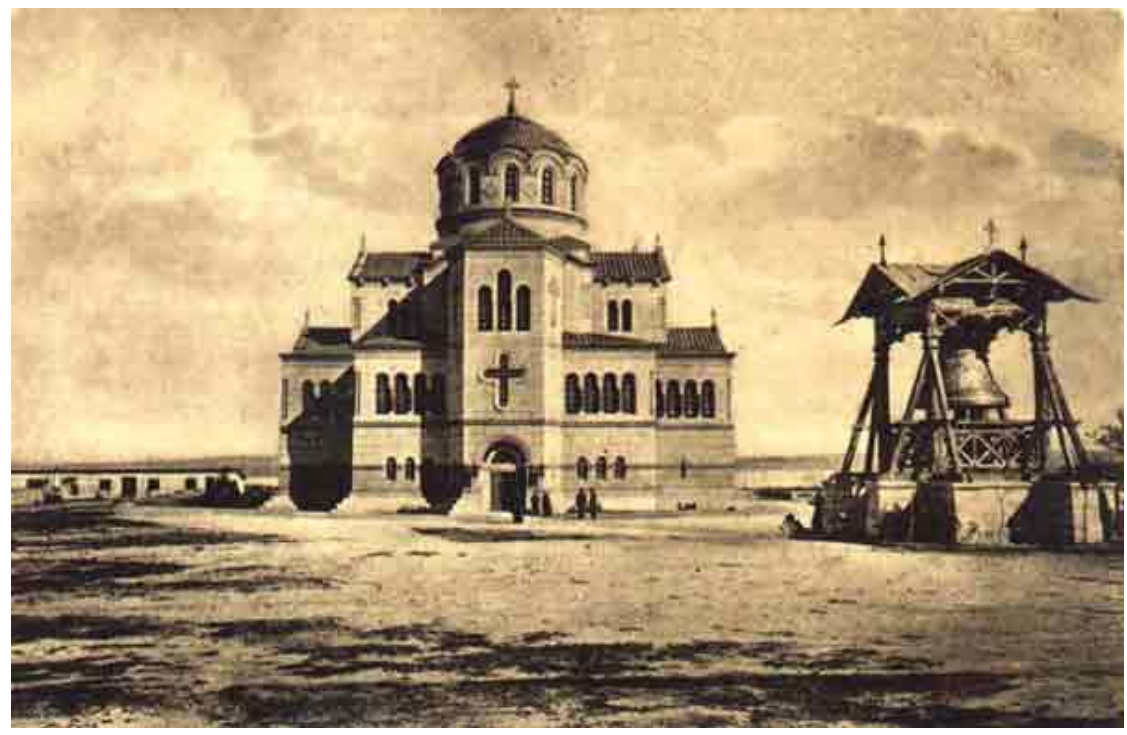

Fig. 4. Chersonesos Cathedral on a pre-revolutionary postcard

Especially note that the epithet «смугле» in the definition of the «глав» of the temple needs a separate and more detailed comment. Of course, in this word-use there is a tribute to the colour that we have already noted, having told about the zinc roof of the cathedral. The colouristic function of this epithet is undeniable in well-known poems about Pushkin in 1911, from the Akhmatova's cycle "In Tsarskoe Selo":

$$
\text { Смуглый отрок бродил по аллеям }<\ldots .>{ }^{40}
$$

${ }^{40}$ Ахматова А. А. Собрание сочинений. В 6 т. - Москва: Эллис Лак, 1998-2002; T. 1. - C. 77 . 
However, in 1913, 1914 and 1915, already outside of any colouristic binding, Akhmatova will give "Pushkin's" colouration to her muse: «А смуглая сидела на траве» («В то время я гостила на земле...» ${ }^{41}$ ), «Допишет Музы смуглая рука» («Уединение» ${ }^{42}$ ), «И были смуглые ноги / Обрызганы крупной росой» («Муза ушла по дороге...» $\left.{ }^{43}\right)$.

In 1916, this epithet will appear again in Akhmatova's poem about Bakhchisaray. Outwardly, it seems to perform a colouristic function again conveys a special shade of Crimean Tatar women' face, personified in the image of “смуглой” autumn:

$$
\begin{aligned}
& <\ldots>\text { Осень смуглая в подоле } \\
& \text { Красных листьев принесла }<\ldots . .{ }^{44}
\end{aligned}
$$

But in the poem "Cleopatra" (1940) it is already unclear: «смуглая грудь», where the heroine puts а «чёрную змійку» with «равнодушной рукой», - is it only a colouristic detail or also a mourning symbol of "farewell pity" to the Egyptian queen ${ }^{45}$ ?

The more examples accumulate, the clearer it becomes: the meaning of the epithet "swarthy" is not limited by colour. This is evidenced by A. A. Blok's poem "Grey morning” - by the way, the same year (1913) as Akhmatova's poems about the Muse:

Прощай, возьми ещё колечко,

Оденешь рученьку свою

И смуглое своё сердечко

В серебряную чешую... ${ }^{46}$

True: Akhmatova in 1916 is talking about a tartar, and A. A. Blok in 1913 - about a gypsy. However, the epithet «смуглый» can’t be explained only by the shade of their skin. Why does Anna Akhmatova write «смуглая» not about just a woman, but about a Muse or an Autumn? And autumn is not something, namely 1916? Why does A. A. Blok's gypsy, saying goodbye to the lyrical hero after the night, full of her passionate songs and his passionate explanations, «хладно жмет» «свои серебряные кольца» to his lips? Does this motive of «страстного холода» and hopeless farewell resonate with the lines addressed to the «утешный» friend in Akhmatova's Bakhchisaray poem?

There may be another purely personal, intimate and psychological reason for Anna Akhmatova's strong attachment to the epithet "смуглый”. From the

${ }^{41}$ Ахматова А. А. Собрание сочинений. В 6 т. - Москва: Эллис Лак, 1998-2002; T. 1. - C. 147.

${ }^{42}$ Ibid. C. 183

${ }^{43}$ Ibid. C. 247

${ }^{44}$ Ibid. C. 275.

${ }^{45}$ Ibid. C. 464.

${ }^{46}$ Блок А. А. Собрание сочинений. В 8 т. - Москва-Ленинград: ГИХЛ, 1960-1963. T. 3. - C. 207. 
very birth she was distinguished by an unusually white skin. In addition to the testimony of contemporaries, this is confirmed by her own recognition: In Chersonesos she "sunburned to the fact that the skin descended" 47 . It is typical for people she belonged to that a stubborn staying in the sun leads not to the tan, but to the peeling skin.

From personal experience Anna Akhmatova knew that such a whiteness is a characteristic sign of people suffering from tuberculosis. In the summer of 1896, her four-year-old sister Irina (Rika) dies from this disease, in the summer of 1906, with the same diagnosis at the age of 21, the elder sister Inna leaves, in the autumn of 192228 years old sister Iya died in Sevastopol. In 1907, Anna Gorenko ${ }^{48}$ was brought to the Dr. E. E. Schmidt mud hospital to be treated from the first signs of tuberculosis.

In the poem «Как невеста, получаю...», written in a tuberculosis sanatorium near Helsinki in October 1915, we read:

Я гощу у смерти белой,

По дороге в тьму. ${ }^{49}$

"White" death, of course, is a multi-valued image. Is it about Finnish snow? It seems to be rather early for October in southern Finland. Or is it about white doctors' robes? Or about shroud? Perhaps. However, there can be one more interpretation. Maybe it's about unhealthy white skin typical to the patients with tuberculosis. In any case, Akhmatova's epithet "white" will always accompany misfortune and trouble ${ }^{50}$. Even paradise, if it is "white", is not immortality, but death ${ }^{51}$.

Does Akhmatova so readily emphasize “смуглое" in the people and objects dear to her because of that? Lyceum Pushkin is swarthy. (He himself all his life considered white skin to be the ideal of beauty.) The autumn in the image of a crimean tartar woman is swarthy. Akhmatova's muse is swarthy. Queen Cleopatra's chest is swarthy. The domes of the Chersonesos temple are swarthy.

And everywhere this Anna Akhmatova's «смуглый» colour is a sign of the desired, dreamed, ideal, but unreachable. Therefore, as a child, she spends her days on the sea, unsuccessfully trying to find such a cherished, but persistently slipping tan under the southern sun.

47 Черных В. А. Летопись жизни и творчества Анны Ахматовой: 1889-1966. Издание 3-е, исправленное и дополненное. - Москва: Издательский центр «Азбуковник», 2016. - C. 53.

${ }^{48}$ Ibid. C. 53.

T. $1 .-$ C. 245 .

${ }^{49}$ Ахматова А. А. Собрание сочинений. В 6 т. - Москва: Эллис Лак, 1998-2002;

${ }^{50}$ Ibid. C. $267,373$.

T. 1. - C. 177.

${ }^{51}$ Ахматова А. А. Собрание сочинений. В 6 т. - Москва: Эллис Лак, 1998-2002; 
So, Akhmatova's poems are tightly soldered among themselves not simply by repeating individual "favourite" words. They are connected by deep poetics. Due to that the words-images are poured into lines, the lines - into whole texts, the texts - into cycles, cycles of different times - into common questions of being, addressed to the heroes of those verses and cycles. But Akhmatova's responses to those questions should be studied carefully again and again.

\section{6. <...> и не знать, что от счастья и славы безнадёжно дряхлеют сердца}

These last two lines on the basis of all accumulated material will help us to understand not only a "small", but also a "big" secret hidden in the poem. In 1912 the poet himself does not know about that.

Let's start with realities as usual. We'll remember that Anna Akhmatova's realities have the habit of quick flowing into poetic images and symbols.

Akhmatova will remember her "main place in the world" on three occasions - Chersonesos, an ancient city-state, included to the list of monuments of the World Cultural Heritage of UNESCO ${ }^{52}$ in 2013. It's the author's (and all the more poet's) will to remember as it was recalled in the 1960s - half a century after childhood and the adolescence associated with Chersonesos. It is the duty of the researchers to check the statements of not only colleagues, but also the authors under study. What does this test show?

"The main place in the world" was reflected in our poet's poems more than modestly. We hurry to note: it refers not to the whole complex of Sevastopol outskirts in the area between Streletskaya and Peschanaya bays, but to antique Chersonesos namely. In the poem «У самого моря» there will be white, steep, limestone Chersonesos coasts, and a flat stone where a "wild girl", girl-mermaid Anya Gorenko was resting, and gold Chersonesos beaches, and capes, and a lot of other things. Then these realities, already in another, mature and bitter context, will be resurrected in the poem «Путём всея земли».

That's true. But these realities are not the details of the ancient Chersonesos namely. And by the 1890s excavations of the ancient Hellenic city, that began its existence in the VI century BC. and became "small Athens" of the Northern Black Sea coast, have already opened much and hit a lot of people ${ }^{53}$. And the city, that came out of the ground, hit not only professionals:

52 Ахматова А. А. Собрание сочинений. В 6 т. - Москва: Эллис Лак, 1998-2002; T. 5. - C. 215, 236, 693.

53 Реальный словарь классических древностей по Любкеру / Под редакцией Ф. Гельбке, Л. Георгиевского, Ф. Зелинского и др. - СПб.: Издание Общества классической филологии и педагогики, 1885. - 1552 с. - С. 280. 
archaeologists, historians, philologists-Hellenists. It was visited by lovers of antiquity, travellers, people of culture. To those, undoubtedly, the Gorenko family belonged, despite their father's non-philological profession.

Yes, Anya Gorenko was born at Bolshoy Fontan in Odessa (also, by the way, the prelusive Odessa suburb). But it is in Chersonesos the relatives will lead their daughter with a full parade to donate a piece of marble with the Greek inscription ${ }^{54}$ found by her to the museum.

Yes, due to difficult family circumstances, Anna Andreyevna's mother with her daughters and her son were forced to move to Evpatoria. However, Evpatoria of Akhmatov's adolescence was extremely colourful, historically rich, multi-faith and multinational city. And the schoolgirl Anya Gorenko, of course, not Boris Balter's high school students - the Evpatoria "boys", remembered at the time of the "thaw" by the entire reading Soviet Union. The author of the story knew that they knew nothing about Juma-Jami (the cathedral mosque of the outstanding Turkish architect Sinan), neither about the unique monastery of the dervishes, nor about the spiritual centre of the Karaites - no less unique Evpatoria kenasses.

Let's suppose, B. Balter's memories could be limited by censorship. But what censorship prevented Akhmatova, mentioning Chersonesos, from remembering the Uvarov basilica, antique bath with its exquisite mosaic, Chersonesites' civilian oath carved on marble? Etc.

The other thing is more likely. The personal "Chersonesos myth" (of, firstly, "wild girl", then "the last inhabitant of Chersonesos") meant for Akhmatova's poetic thinking more than the realities of historical Chersonesos. Note: the realities of historical Bakhchisaray (both ancient and 1916) are also obscured in her poem «Вновь подарен мне дремотой...» by the personal "Bakhchisaray myth", the myth of "gold" but timeless(!) Bakhchisaray, the place of action of her with N.V. Nedobrovo last lyrical plot ${ }^{55}$.

Realities, as we see, really flow into symbols in the poet's creative consciousness, and personal myths are woven from symbols.

Anna Andreevna in the autumn of 1912 (the time of writing the poem) was already 23 years old. It was considerable age for the most popular female

54 Черных В. А. Летопись жизни и творчества Анны Ахматовой: 1889-1966. Издание 3-е, исправленное и дополненное. - Москва: Издательский центр «Азбуковник», 2016. - С. 32 .

55 See special cycle of publications about that: Казарин В. П., Новикова М. А. Стихотворение А. А. Ахматовой «Вновь подарен мне дремотой...»: (Опыты реального комментария). Publication 1 // Анна Ахматова: эпоха, судьба, творчество. Крымский Ахматовский научный сборник. Вып. 10. - Симферополь: Крымский Архив, 2012. C. 60-72; Publication 2 // Вопросы русской литературы: Межвузовский научный сборник. Вып. 24 (81). - Симферополь: Крымский Архив, 2012. - C. 11-18; Publication 3 // Сайт «Бахчисарайский историко-культурный заповедник» (biks.org). - 06.06.2013. 
poet of the Silver Age. But let's think: and does she "know" not only in 1903, but even in 1912, how «от счастья и славы безнадёжно дряхлеют сердца»?

And Akhmatova will think and will think with partiality about "happiness" and "glory" for a long time, in fact, until the end of her days (see the prophetic line of 1912 «Умирая, томлюсь о бессмертьи...», opening the second of five poems of Akhmatova's cycle in «Гипербореe»). It was evidenced by her resentment against contemporaries, Russian emigrants, as if they locked her in the 1910s - early 1920s and forgot about her later: writing, suffering, but also maturing. In the same row there is Akhmatova's attention to her foreign researchers, to their publications of the 1960s and a lively reaction to the literary award "Etna-Taormina" and conversations with friends about a possible "Nobel”, etc. It's possible to understand Anna Andreyevna. It's not easy test to drink full cup of that very glory by mid-twenties and then to sink into isolation, fame in a narrow, very narrow circle for thirty more years. However, another thing is important for our topic. "Beauty of the thirteenth year”, Akhmatova did not bind her glory with heart senescence then.

Akhmatova in 1912 is the author of the first book of poems «Вечер",

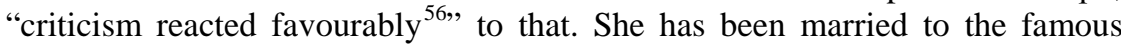
N. Gumilev for two and a half years. They had a son Lev. Every year Akhmatova visits Europe. There she is surrounded by extraordinary people and large cultural events (for example, "first triumphs of the Russian ballet" in Paris [ibid.]). She is all in the whirlpool of passions, courtship, novels.

Let's say: it's not about the corny "femme fatale" - fashionable female type of the Silver Age, so sharply impersonated by L. Tolstoy in his "Sisters". Count Tolstoy, returning from immigration to the USSR, hurried up to repel with the iconic figures of that century, who didn't choose him as a significant figure. So, Tolstoy's poet Bessonov is a proven parody of A. A. Blok. In this case, why not assume that Bessonov's resort (Crimean!) passion, actress (that is an artistic woman), thin, with a snake plastic, is a hidden parody of Akhmatova? After all, in the eyes of the general public, both poets were the symbol and legend of the Silver Age: he - as his ideal man, she - as his ideal woman. So, for the mass mythology, the "novel" between them was meant by itself. But now we are interested not in these myths and parodies, but the fact: Akhmatova's poetry and personal biography, endlessly distant from them, still fed them.

So, Akhmatova in 1912 does not feel herself either declining in her heart, nor indifferent to happiness and glory. Where did these lines appear in the final of the poem? Who pronounces them?

${ }^{56}$ Ахматова А. А. Сочинения. В 2 т. - Москва: Художественная литература, 1986. T. 2. - C. 237. 
Before the answer (requiring further verification), we will pay attention to the Akhmatova's verb in the previous lines: «Всё глядеть бы на смуглые главы / Херсонесского храма...». «Глядеть» means not the same as "look around". Let's try to change the verb: «Поглядеть бы на смуглые главы...». Then the meaning of the final quatrains is approximately the following: to come again to the memorable places of adolescence, to see them and not to guess in blissful ignorance what the teenage heroine could not know yet: the price of her future adult glory and happiness.

But it's exactly what she already knows!

An important shade of the meaning of the verb "to look" (as in the case with the verb "see") is its duration. "To look" for a long time can, of course, mean "admire", but not in Akhmatova's poetic world. There are many landscapes in it, they are almost in her every lyrical miniature. There is no contemplative, non-dialogical love: neither natural world nor urban landscapes.

If the heroine looks at the «смуглые главы» of the Chersonesos temple, then these domes also look at her? If she conducts her mental dialogue with them (the entire previous part of the poem is such a dialogue), then the «смуглые главы» have such a dialogue with the heroine? Then it is permissible to assume that the final line and a half is also their answer to her - answer and prophecy, answer and warning for coming years and decades. She may not know it - they know it. Being ready to understand the "small" mystery, she will hear everything that will be said to her. And as a result, she will be ready for the "big" mystery of a serious life test by half-oblivion and neglect.

Odessa letter from N.S. Gumilev testifies that the final two lines of the poems about "happiness and glory" have double addressing. Chersonesos temple addressed it to Akhmatova, but she readdressed it to N.S. Gumilev, that was confirmed by his answer.

Such a hypothesis highlights the observations we have made before. It turns out, that it is not without reason Akhmatova calls «смуглые» the domes of the Chersonesos temple and the Bakhchisaray autumn, that brought red leaves in the hem, and the muse who came to the poet along the mountain road (that is, from a certain height). All of them are actors (not "background"), all of them have their own, higher point of view, their voice in the dialogue with the poet.

Let's say that autumn does not just strew the leaves on the stairs, where the heroine "said goodbye" to the hero. This gesture is also a cue, and a cue with many values. The road is strewn with flowers for the groom and the bride at the wedding. Dry autumn leaves are a kind of antipode of the wedding ceremony. The funerary procession is also strewn with flowers. But the bright, "passionate" red colour disproves this interpretation as the only possible, without canceling the tart funerary taste brought to the situation of forgiveness. "To bring in the hem" is a folk phraseologism, it means "to give birth to a child 
on the side, outside the legal marriage”. However, Bakhchisaray autumn brings to the heroes not an alive baby, the fruit of love, but dead leaves, the fruit of the meeting "on the side". (It should be reminded: Akhmatova by the time of that meeting broke up, but without "church debunking" with N.S. Gumilev, who was at war. And a beautiful wife, selflessly caring for her sick husband, waits for N.V. Nedobrovo in Alushta.)

The same conclusion applies to the «смуглой» Muse. Her swarthiness can also be interpreted as a colour-reality (Crimean? Italian?). At the same time, the swarthy Muse, who will again and again come to our poet, will not be the one who "dictates" the pages of "Purgatory" or the pages of "Paradise" to Dante. According to Akhmatova, she dictated the pages of "Hell" 57 .

Reflections from these two lines will ripple far ahead - to «Реквием», with its political dungeons, and to «Поэмы без героя», with its diabolical carnival. And the Crimean Akhmatova does not yet guess about this future. But it is already known to her "swarthy" interlocutor and to «смуглые главы» of the Chersonesos temple...

\section{CONCLUSIONS}

It's impossible to finish (as we have seen) a conclusion to the topic "Akhmatova and Crimea”: there's a lot of work to do here for a long time. In our opinion, today it is possible to state: in Akhmatova's fate Crimea played a role similar to its role in Pushkin's fate. Multi-voiced, multicultural, "dialogical" and metaphysical Crimea charged with these properties all great artists who fell into its power field.

\section{The proposed version of the commentary}

on the "Chersonesos" fragment of the poem by A. A. Akhmatova: Всё глядеть бы на смуглые главы

Херсонесского храма с крыльца <...>.

It is about a holiday village built by $\mathrm{N}$. Tur, the owner of the estate "Otrada” near Streletskaya Bay. In this village, the Gorenko family rented a cottage almost every summer from 1896 to 1903. As we know, A.A. Akhmatova called Chersonesos "the main place in the world" for her. It is not possible to determine where the cottage was located and to find out whether the family changed their summer address for eight years. We can say with certainty only that the summer cottage stood on an elevated place, so she could clearly see Chersonesos and, in particular, the St. Vladimir Cathedral "from the

${ }^{57}$ Ахматова А. А. Собрание сочинений. В 6 т. - Москва: Эллис Лак, 1998-2002; T. 1. - C. 403. 
porch". The dome of the temple and its two-tiered roofs had a dark zinc-lead coating and visually created the effect of a multi-domed cathedral. That gave rise to the poetic image of the "swarthy domes of the Chersonesos temple".

\section{SUMMARY}

The paper reveals Petersburg and Crimean realia underlying the poetic imagery in Anna Akhmatova's poem written in 1912. Among the Petersburg realia there are the main Maritime Customs House with its special flag and Prof. D. Ott's clinic founded in 1797 by Empress Maria Feodorovna and widely referred to as the Imperial Maternity Home. Among the Crimean realia there are the suburbs of Sevastopol (with N. Tour's estate Otrada and Dr. E. Schmidt's mud cure clinic), the Streletskaya and Pesochnaya Bays, Chersonese and St. Vladimir's Cathedral. New insights into the circumstances which inspired Akhmatova's text are offered such as the birth of her son Leo and her estrangement (as well as subsequent official divorce) from N. Gumilev. The double addressee of the poem is proved, as well as a special prophetic meaning of its final part. The historical and biographical methods are combined in the research with realia comments and in-depth poetological analysis. The text is interspersed with illustrations.

\section{REFERENCES}

1. Ахматова А. А. Собрание сочинений. В 6 т. - Москва: Эллис Лак, 1998-2002; Т. 7 (дополнительный). - 2004.

2. Ахматова А. А. Сочинения. В 2 т. - Москва: Художественная литература, 1986.

3. Ахматова А. А. Сочинения. В 2 т. - Москва: Правда, 1990.

4. Ахматова А. А. Победа над судьбой. В 2 т. - Москва: Русский путь, 2005.

5. Ахматова А. А. Стихотворения и поэмы / Составление, подготовка текста и примечания В. М. Жирмунского. - Издание 2-е. Ленинград: Советский писатель, 1977. - (Библиотека поэта. Большая серия).

6. Черных В. А. Летопись жизни и творчества Анны Ахматовой: 1889-1966. - Издание 3-е, исправленное и дополненное. - Москва: Издательский центр «Азбуковник», 2016.

7. Горелов В. Н. Херсонес Анны Ахматовой // Литературная газета + Курьер культуры: Крым-Севастополь: Региональное обозрение. 2008. - 26 сентября-10 октября. - №18(23). - С. 2.

8. Севастополь: Энциклопедический справочник. Издание 2-е, дополненное и исправленное. - Севастополь: «Салта» ЛТД, 2008. 
9. Золотарёв М. И., Хапаев В. В. Херсонесские святыни. Севастополь: Фуджи-Крым, 2002.

10. Блок А. А. Собрание сочинений. В 8 т. - Москва-Ленинград: ГИХЛ, 1960-1963.

11. Реальный словарь классических древностей по Любкеру / Под редакцией Ф. Гельбке, Л. Георгиевского, Ф. Зелинского и др. - СПб.: Издание Общества классической филологии и педагогики, 1885. - 1552 с. - C. 280.

12. Гумилёв Н. С. Сочинения. В 3 т. - Москва: Художественная литература, 1991.

13. Витухновская Н. И., Зубарев А. А. Морские врачи и Севастопольская морская офицерская библиотека // Сайт «Графская пристань» (grafskaya. com).

14. Казарин В. П., Новикова М. А. Стихотворение А. А. Ахматовой «Вновь подарен мне дремотой...»: (Опыты реального комментария). Публикация 1 // Анна Ахматова: эпоха, судьба, творчество. Крымский Ахматовский научный сборник. Вып. 10. - Симферополь: Крымский Архив, 2012. - С. 60-72; Публикация 2 // Вопросы русской литературы: Межвузовский научный сборник. Вып. 24 (81). - Симферополь: Крымский Архив, 2012. - С. 11-18; Публикация 3 // Сайт «Бахчисарайский историкокультурный заповедник» (biks.org), - 06.06.2013.

\section{Information about the author:} Kazarin V. P., Doctor of Philology, Professor, Acting Rector,

V. I. Vernadsky Taurida National University 31, J. McCain str., Kyiv, 01042, Ukraine 